\title{
PENGALAMAN IBU MERAWAT BALITA USIA 6 - 24 BULAN BERSTATUS GIZI BURUK
}

\section{THE EXPERIENCE OF MOTHERS CARING FOR TODDLERS AGED 6 - 24 MONTHS WITH MALNUTRITION}

\author{
Melantika Nur Fitria Syahri ${ }^{1}$, Tiyas Kusumaningrum ${ }^{2}$, Bagus Setyoboedi ${ }^{2}$ \\ 1. Program Studi Pendidikan Bidan, Fakultas Kedokteran, Universitas \\ Airlangga \\ 2. Fakultas Kedokteran, Universitas Airlangga \\ Alamat korespondensi: \\ J1. Terung Kulon, Sidoarjo, 61262 Indonesia \\ Email : melan.syahri@gmail.com
}

\begin{abstract}
Abstrak
Latar Belakang : Gizi buruk adalah penyumbang angka morbiditas dan mortalitas pada anak. Dinas Kesehatan Kota Surabaya menyatakan kasus gizi buruk secara $100 \%$ telah teratasi. Fakta menunjukkan di kecamatan Sukomanunggal mengalami peningkatan angka gizi buruk. Pemerintah telah melakukan upaya perbaikan melalui program - programnya, tetapi kualitas perawatan dan pola asuh ibu belum diketahui. Sehingga dilakukanlah penelitian untuk mengeksplorasi pengalaman ibu dalam merawat anak balita usia 6-24 bulan dengan status gizi buruk post diagnosis di kecamatan Sukomanunggal kota Surabaya. Metode : Penelitian ini merupakan penelitian kualitatif. Jumlah partisipan sebanyak 15 partisipan dan dipilih menggunakan metode purposive sampling. Variabel dalam penelitian ini adalah pengalaman ibu. Teknik pengumpulan data yang digunakan adalah wawancara mendalam dilengkapi dengan catatan lapangan. Hasil : Hasil penelitian didapatkan $(53 \%)$ ibu mengubah pola pemberian makan (jumlah, menu, frekuensi) dan dari $(53 \%)(83,3 \%)$ memberikan makanan secara aktif dan responsif. Ibu memiliki persepsi bahwa masalah gizi pada balita disebabkan faktor keturunan (60\%) dan faktor nafsu makan (40\%). Ibu memberikan makanan tambahan (selingan) berupa snack sehat (80\%) dan makanan ringan (20\%). Ibu tidak memberikan vitamin kepada balitanya (53\%). Ibu memiliki pola PHBS yang baik, yaitu (87\%) balita tidak memiliki kebiasaan memasukkan barang yang dipegangnya ke mulut dan (53\%) ibu mengajari serta membiasakan balita mencuci tangan. Ibu memiliki tingkat kepatuhan yang baik terhadap program puskesmas, (73\%) ibu rutin membawa balitanya ke posyandu, (67\%) ibu patuh memberikan PMT$\mathrm{P},(87 \%)$ ibu mengimunisasikan balita secara lengkap, dan (54\%) ibu memberikan obat cacing rutin kepada balitanya. Tetapi hanya (26\%) ibu yang melakukan konsultasi ke tenaga kesehatan. Kesimpulan : Perawatan yang dilakukan oleh ibu terhadap balitanya yang mengalami gizi buruk, yaitu melakukan perubahan pola pemberian makan dengan strategi praktik pemberian makan yang aktif dan responsif, memberikan makanan tambahan (selingan) berupa snack sehat yang berbahan lokal serta mengurangi konsumsi makanan ringan yang berlebihan, menerapkan Perilaku Hidup Bersih dan Sehat (PHBS), patuh terhadap program puskesmas dan melakukan konsultasi lebih lanjut ke tenaga kesehatan.
\end{abstract}

Kata Kunci : Status Gizi, Balita, Gizi buruk, Pemberian Makanan

\section{Abstract}

Background : Malnutrition is a contributor to the morbidity and mortality rates in children. The Surabaya City Health Office stated that cases of malnutrition were 100\% resolved. The facts show

e-ISSN 2656-7806 (C) 2019

Published by Universitas Airlangga .This is an Open Access (OA) article distributed under the terms of the Creative Commons Attribution Share-Alike 4.0 International License (https://creativecommons.org/licenses/by-sa/4.0/). DOI: 10.20473/imhsj.v3i1.2019.1-15 
that in Sukomanunggal there has been an increase in the number of malnutrition. The government has made efforts to improve through its programs, but the quality of care and parenting is unknown. So a study was conducted to explore the experiences of mothers in caring for toddlers aged 6-24 months with malnutritional's status post diagnosis in Sukomanunggal, Surabaya. Method : This research was a qualitative study. The number of participants was 15 participants and was selected using the purposive sampling method. The variable in this study was the experience of mothers. The data collection technique used was indepth interviews equipped with field notes. Results : The results showed that (53\%) mothers changed their feeding patterns (number, menu, frequency) and from (53\%) (83.3\%) gave food actively and responsively. Mother had a perception that nutritional problems in toddlers were due to heredity (60\%) and appetite factors (40\%). Mothers provided additional food (interlude) in the form of healthy snacks (80\%) and snacks (20\%). Mothers did not give vitamins to their children (53\%). Mothers had a good hygienic habits pattern, that was (87\%) toddlers did not have the habit of entering the items they hold in their mouths and (53\%) mothers teach and get children to wash their hands. Mothers had a good level of adherence to the puskesmas program, (73\%) mothers routinely brought their babies to posyandu, (67\%) mothers obediently gave supplementary feeding, (87\%) mothers fully immunized their children, and (54\%) mothers gave medication routine worms to her toddler. But only (26\%) mothers consulted health workers. Conclusion : The care performed by mothers on their children who experience malnutrition, it is changing the pattern of feeding with an active and responsive feeding practice strategy, providing supplementary food in the form of healthy snacks made locally and reducing excessive consumption of snacks, apply hygienic habits, adhere to the puskesmas program and conduct further consultations with health workers.

Keywords : Nutritional status, Toddler, Malnutrition, Feeding

\section{PENDAHULUAN}

Anak adalah aset sekaligus calon pemimpin suatu negara di masa depan (Kemenkes R1, 2016). Kualitas anak di masa depan ditentukan oleh derajat kesehatan anak pada masa balita (0 - 60 bulan) (Liansyah, 2015). Periode emas pada masa balita adalah usia 0 sampai dengan 24 bulan. Pada periode ini pertumbuhan dan perkembangan anak terjadi dengan sangat pesat (Septikasari, 2018). Tetapi periode ini juga bisa disebut sebagai periode kritis sebab pada periode ini anak rentan terhadap pengaruh negatif, seperti kekurangan gizi dan penyakit. Indikator keberhasilan kesehatan pada balita dapat dinilai dari status gizi balita tersebut. (Khasanah dan Sulistyawati, 2018).

Gizi buruk adalah salah satu masalah kesehatan penyumbang angka morbiditas dan mortalitas pada anak (Nangalu et al., 2016). Menurut hasil Pemantauan Status Gizi (PSG) tahun 2016 terdapat 3,1\% anak balita usia $0-23$ bulan di Indonesia mengalami gizi buruk. Di Jawa Timur menurut sumber data yang sama, terdapat 2,6\% anak balita usia $0-23$ bulan mengalami gizi buruk. Menurut Profil Kesehatan Dinas Kesehatan (Dinkes) Kota Surabaya tahun 2017 terdapat 278 balita mengalami gizi buruk. Angka ini menunjukkan suatu penurunan dibandingkan dengan tahun sebelumnya yaitu sebesar 280 balita pada tahun 2016. Tetapi 
penurunan tersebut juga diikuti dengan penurunan jumlah balita yaitu dari 176.439 pada tahun 2016 menjadi 171.213 balita pada tahun 2017. Berdasarkan Profil Kesehatan Kota Surabaya tahun 2017, daerah penyumbang gizi buruk tertinggi di Surabaya adalah kecamatan Sukomanunggal yaitu sebanyak 63 balita.

Ibu selaku primary care memiliki keterlibatan langsung terhadap status gizi anak (Widayani et al., 2016). Kepedulian dan pengetahuan ibu terkait kesehatan balita memiliki peranan besar terhadap perbaikan status gizi buruk pada anak (Rezaei et al., 2014). Kepedulian dan pengetahuan ibu yang baik memiliki hubungan yang positif terhadap kualitas perawatan dan pola asuh pada balita, misalnya pola pemberian makan, pola hidup bersih dan sehat, dan pemanfaatan fasilitas kesehatan balita (Marmi dan Rahardjo, 2012).

Pemerintah melakukan upaya penanganan dengan memasukkan program perbaikan gizi ke dalam program pokok Puskesmas, tetapi kualitas perawatan dan pola asuh ibu terhadap balita yang mengalami gizi buruk masih belum diketahui. Tujuan dilakukan penelitian ini adalah untuk mengeksplorasi pengalaman ibu dalam merawat anak balita usia 6 - 24 bulan dengan status gizi buruk.

\section{METODE}

Tempat penelitian dilakukan di kecamatan Sukomanunggal kota Surabaya.

Desain Penelitian jenis penelitian yang digunakan dalam penelitian ini adalah penelitian kualitatif. Populasi dalam penelitian ini adalah semua ibu yang memiliki anak balita dengan status gizi buruk pada tahun 2017 dan 2018 di wilayah kerja puskesmas Simomulyo dan puskesmas Tanjungsari kecamatan Sukomanunggal.

Teknik sampling sampel dalam penelitian kualitatif dinamakan sebagai partisipan. Partisipan dalam penelitian ini dipilih dengan menggunakan metode purposive sampling berdasarkan kriteria inklusi yaitu : Balita tercatat mengalami gizi buruk (<-3 SD) di buku laporan tahunan balita gizi buruk puskesmas Simomulyo dan Tanjungsari pada tahun 2017 dan tahun 2018 dan kondisi balita saat dilakukan penelitian dalam status gizi baik (-2 SD s/d 2 SD) atau gizi kurang (-3 SD s/d <-2 SD) atau gizi buruk (<-3 SD). Kriteria ekslusi penelitian yaitu : Balita mengalami gangguan sejak lahir pada sistem saluran cerna, metabolisme, kromosom, atau kelainan bawaan jantung, dan ginjal berdasarkan data dari puskesmas dan balita 
dengan HIV berdasarkan data dari puskesmas. Jumlah partisipan dalam penelitian ini adalah sebanyak 15 partisipan. Jumlah partisipan pertama yang dipilih dengan menggunakan metode purposive sampling sejumlah 10 orang. Kemudian ditambahkan partisipan lagi sampai mencapai saturasi data atau pengulangan informasi pada partisipan yang ke - 15 .

Pengumpulan data adalah wawancara secara mendalam (indepth interview) yang dilengkapi dengan catatan lapangan.

Analisis data pada penelitian ini melakukan analisis dengan menggunakan metode analisis Collaizi, yaitu dengan membaca transkrip yang telah dibuat secara berulang - ulang, mengelompokkan kata - kata kunci, membuat kategori - kategori, mengelompokkan kategori dalam subtema, merumuskan tema, kemudian mengintegrasikan hasil analisis ke dalam bentuk deskriptif.

\section{HASIL DAN PEMBAHASAN}

Karakteristik partisipan dalam penelitian ini menunjukkan mayoritas ibu balita dengan gizi buruk berusia 20 - 35 tahun, pekerjaan ibu rumah tangga, pendidikan terakhir SMA, jumlah anak 2 orang, dan pendapatan keluarga perbulan 1 - 3 juta perbulan dengan jumlah anggota keluarga yang ditanggung 4 - 5 orang. Status gizi balita menunjukkan suatu perbaikan dilihat dari peningkatan nilai Z-score, meskipun hasil belum sesuai dengan harapan yaitu menjadi berstatus gizi baik.

Dari analisis data hasil wawancara mendalam yang telah dilakukan, beberapa tema dan subtema menunjukkan bagaimana cara ibu dalam merawat anak balita usia 6 - 24 bulan dengan status gizi buruk. Secara keseluruhan tema utama yang muncul meliputi :

\section{Tema 1 : Pola pemberian makan pada balita}

Pola pemberian makan pada balita dibagi menjadi dua subtema, yaitu

\section{1) Perubahan pola makan (Porsi, Menu, Frekuensi)}

Dari analisis data hasil wawancara menunjukkan bahwa (53\%) atau 8 orang ibu merubah pola pemberian makan pada balita, sedangkan (47\%) 7 orang ibu lainnya tidak merubah pola pemberian makan atau sama seperti sebelum balita terdiagnosa gizi buruk. 
"Saya sudah coba kasih makan tiga kali sehari mbak tapi ya itu susah makannya"

"Untuk menunya ya paling sayur sop gitu sama tempe, telur"

"Mau kok mbak anaknya, semua jenis sayur di sop mau kok dia"

"Tahu tempe gitu dia mau juga mbak, ikan juga mau kayak pindang gitu dia suka” (R02)

"Ya paling nasinya itu satu centong mbak sama sop sama telur dadar tadi"

"Bisa lebih dari 3 kali makannya mbak kalau pakai sayur sop itu"

"Tapi cuma mau wortelnya aja mbak kalau sop itu yang lainnya kayak kentang kubis gitu nggak mau dia"

"Kalau sayur ya cuma itu mbak, yang lainnya lo nggak mau"

"Sudah pernah saya coba sayur lain sih mbak, tapi dia nggak mau, maunya cuma itu (sayur sop) tapi tak kasih telur dadar gitu daripada dia nggak mau makan" (R04)

\section{2) Strategi Ibu}

Dari 8 ibu yang melakukan perubahan pada pola pemberian makan $83,3 \%$ (6 orang ibu) memberikan makanan secara telaten kepada anaknya dengan cara menyuapi, makan sambil bermain, ataupun memberi makanan sesuai dengan selera anak, sedangkan 16,7\% (2 orang ibu) sisanya memberikan makanan dengan cara memaksa anak.

"Saya suapi mbak sambil dia mainan gitu mbak" (R01)

“Perlu dibujuk - bujuk diajak main gitu kalau mau makan” (R02)

Gizi buruk adalah suatu kondisi kekurangan energi kronik baik dari segi jumlah maupun komposisi zat gizi yang berlangsung lama (Wiyono, 2016). Kurang atau tidaknya energi ini dipengaruhi oleh pola makan balita. Dalam menentukan pola makan balita, seorang ibu harus memiliki pengetahuan mengenai bahan makanan, jumlah kalori yang dikandung setiap makanan, dan kebutuhan harian balita terhadap energi, karbohidrat, lemak, dan protein (Abidin, 2012). Pengetahuan ibu akan mempengaruhi kualitas pola asuh ibu terhadap balita, khususnya pola asuh pemberian makan. Menurut Munawaroh (2015) dan Suyatman (2017) pola asuh pemberian makanan oleh ibu mempunyai hubungan yang signifikan terhadap status gizi balita. Semakin baik pola pemberian makan yang diberikan maka semakin baik status gizi balita dan sebaliknya.

Menurut penelitian yang dilakukan oleh Kusumaningtyas (2017) dan Natalia (2015) dalam proses pemberian makan diperlukan keseimbangan antara porsi, 
menu, dan frekuensi makanan. Selain itu dalam proses pemberian makan juga diperlukan suatu strategi khusus. Menurut teori pengelolahan gizi, strategi khusus yang dimaksud adalah dengan memberikan makan secara aktif dan reponsif (Wiyono, 2016). Caranya yaitu dengan memberikan makanan sesuai dengan umur anak, mengetahui kapan waktu anak makan, serta berupaya untuk meumbuhkan nafsu makan anak dengan cara membujuk dan menciptakan suasana makan anak yang baik, hangat, dan nyaman (Arredondo, 2011).

\section{Tema 2 : Persepsi Atas Masalah Gizi Balita}

Persepsi atau kepercayaan ibu atas penyebab masalah gizi pada balita dibagi menjadi dua subtema, yaitu :

\section{1) Nafsu makan anak}

Dari analisis data hasil wawancara mendalam yang telah dilakukan didapatkan (40\%) atau 6 orang ibu menyatakan bahwa gizi buruk yang dialami oleh balitanya disebabkan oleh faktor nafsu makan yang kurang baik atau susah makan.

"Saya rasa beratnya nggak naik - naik itu mungkin karena dia makannya susah itu mbak" (R02)

"Ya itu mbak anaknya itu susah makannya, dia itu ndak mau nasi dulu itu maunya cuma bubur aja” (R03)

\section{2) Faktor Keturunan}

Dari analisis data hasil wawancara mendalam yang telah dilakukan didapatkan $(60 \%)$ atau 9 orang ibu percaya bahwa gizi buruk yang yang dialami oleh balitanya disebabkan karena adanya faktor keturunan dari ibu ataupun sang ayah.

"Saya pikir ya gak papa mungkin keturunan dari ayahnya kan kurus mbak, cuma ya itu kalau sakit aja jadi lemes tidur terus, terus bobotnya turun pas penimbangan" (R01)

"ya tetep seperti biasanya wong anaknya lo makannya semua juga mau tapi nggak bisa gemuk gemuk” (R07)

Faktor nafsu makan erat kaitannya dengan kecukupan asupan energi. Seorang anak yang memiliki nafsu makan kurang baik menyebabkan ketidakcukupan zat gizi, sebab jumlah kalori yang masuk tidak seimbang dengan energi yang dikeluarkan (Supriasa, 2012). Menurut penelitian yang dilakukan oleh Kusumaningtyas (2017) sebagian besar balita dengan kecukupan energi yang kurang berpeluang lebih besar (97,3\%) memiliki gizi kurang dibandingkan dengan 
memiliki gizi yang baik. Apabila ketidakcukupan ini berlangsung lama maka cadangan jaringan akan digunakan untuk memenuhi ketidakcukupan tersebut sehingga terjadilah kemerosotan jaringan yang ditandai dengan penurunan berat badan (Supriasa, 2012).

Menurut penelitian yang dilakukan oleh Miko dan Agus (2017), status gizi seorang anak selain dipengaruhi keadaan gizi juga dipengaruhi oleh faktor keturunan. Faktor keturunan yang dimaksud adalah apabila orangtua mengalami malnutrisi maka akan melahirkan anak - anak yang malnutrisi juga. Malnutrisi atau gizi buruk disebabkan karena ketidakcukupan nutrisi dan infeksi penyakit. Kedua faktor penyebab ini dipengaruhi kebiasaan hidup dalam suatu keluarga. Jika dalam suatu keluarga terbentuk pola kebiasaan makan dan PHBS (Perilaku Hidup Bersih dan Sehat) yang tidak baik maka hal itu juga akan terjadi pada siklus kehidupan anak (Widayani, 2016). Apabila pada periode emas balita terjadi masalah akibat kebiasaan hidup yang tidak baik ini dan berlangsung dalam waktu yang lama maka munculah suatu dampak negatif yang bersifat irreversible di kehidupan balita mendatang (Septikasari, 2018). Secara tidak langsung balita yang mengalami gizi buruk ini ketika dewasa dan kemudian memiliki anak besar kemungkinan anaknya juga akan mengalami gizi buruk (Mohseni et al., 2017).

Masing - masing persepsi ini mempengaruhi proses pola asuh dan perawatan terhadap balita di kedepannya. Ibu yang memiliki persepsi bahwa faktor nafsu makan adalah penyebab masalah gizi pada balita, maka ibu akan berupaya mengubah pola pemberian makan, membelikan vitamin, dan melakukan konsultasi ke tenaga kesehatan. Tetapi ibu yang memiliki persepsi bahwa faktor keturunan adalah penyebab masalah gizi pada balita, maka ibu akan menerima kondisi yang dialami oleh balitanya dan tidak melakukan upaya apapun lagi. Perilaku ibu terhadap kepercayaan atau persepsi tentang gizi buruk sejalan dengan teori health beliefe model yang dikembangkan oleh Rosenstock (1988). Bahwa perilaku kesehatan ditentukan oleh kepercayaan, keyakinan, dan persepsi tentang penyakit dan strategi yang tersedia untuk mengurangi terjadinya penyakit.

\section{Tema 3 : Makanan Tambahan (Selingan)}

Makanan tambahan (selingan) yang diberikan oleh ibu secara mandiri kepada balita dibagi menjadi 3 subtema : 


\section{1) Snack Sehat}

Dari analisis data hasil wawancara mendalam yang telah dilakukan didapatkan dari 15 orang ibu $(80 \%)$ atau 12 ibu memberikan balitanya cemilan yang sehat seperti biskuit PMT-P dari puskesmas, buah, dan susu.

"Ya buah yang dia mau cuma pisang itu mbak lainnya nggak mau"

"Sama susu tapi bukan susu formula tapi susu tinggal minum itu"

"Sehari sekali doang mbak"

"Iya nyemil biskuit dari puskesmas itu"

"Oh jarang mbak kalau ciki - cikian gitu, seringnya ya itu es krim gitu” (R04)

\section{2) Makanan Ringan}

Dari analisis data hasil wawancara mendalam yang telah dilakukan didapatkan bahwa dari 15 partisipan (20\%) atau 3 orang ibu memberikan cemilan berupa ciki - cikian, pentol/bakso, sosis, dan biskuit dengan kandungan gula tinggi atau pemanis buatan.

"Ciki - cikian mbak dia suka banget, hampir setiap hari beli" (R01)

"Iya mbak nyemil mbak dia suka jajan mbak daripada makan gitu, kadang dia kalau mau jajan nggak dibelikan gitu dia ngambek"

"Ya kayak biskuit wafer nabati"

"Sejak umur 1,5 tahun sih mbak dan sering anaknya pokok e suka jajan, makanya mungkin jadi nggak nafsu makannya” (R03)

\section{3) Vitamin}

Dari analisis hasil wawancara didapatkan bahwa dari 15 partisipan (47\%) atau 7 orang ibu memberikan vitamin sebagai penambah nafsu makan balitanya, sedangkan $(53 \%)$ atau 8 orang ibu tidak memberikan vitamin atau hanya memberikan ramuan sesuai dengan kepercayaannya.

"Oh iya mbak saya belikan vitamin dan penambah nafsu makan juga anaknya itu tapi ya tetep makannya sulit, jajan aja sukanya mbak” (R03)

"Iya mbak tak belikan curcuma dulu itu tapi ya tetep mau makannya ya pas udah 2 tahun lebih ini" (R05)

Pemberian makanan tambahan adalah upaya untuk memberikan tambahan makanan guna mencukupi kebutuhan gizi agar tercapainya status gizi yang baik (Depkes, 2011). Balita yang mengalami gizi buruk memerlukan asupan kalori yang lebih besar dibandingkan balita yang bergizi baik. Salah satu cara untuk mencukupi kebutuhan tersebut adalah dengan memberikan makanan tambahan. Makanan tambahan pemulihan diutamakan berbasis bahan makanan lokal dari makanan keluarga dan sebaiknya tidak memberikan anak makanan tambahan atau selingan 
berupa snack (ciki - cikian), permen, kerupuk, dan lainnya yang dapat mempengaruhi nafsu makan anak (Widayani, 2016).

Hasil dari penelitian ini menunjukkan sebagian besar ibu tidak memberikan vitamin sebagai usaha dalam perbaikan gizi balita. Padahal menurut penelitian yang dilakukan oleh Herlina (2014) bahwa terdapat hubungan yang signifikan antara pemberian suplemen multivitamin dengan status gizi balita 1-5 tahun di Posyandu Pala VII Notoprajan Yogyakarta Tahun 2014. Pada penelitian yang dilakukan oleh herlina ini orangtua memberikan suplemen multivitamin dengan alasan sebagian besar untuk menjaga kesehatan anak yaitu $(65,7 \%)$ dan untuk meningkatkan nafsu makan anak $(25,7 \%)$.

\section{Tema 4 : Perilaku Hidup Bersih dan Sehat (PHBS)}

Perilaku Hidup Bersih dan Sehat (PHBS) yang berkaitan dengan penyakit infeksi (diare, demam, batuk, pilek) penyebab gizi buruk pada balita dibagi menjadi 2 subtema :

\section{1) Memasukkan Barang Ke Mulut}

Dari analisis data hasil wawancara mendalam yang telah dilakukan didapatkan (87\%) atau 13 orang balita tidak memiliki kebiasaan memasukkan barang apapun yang dipegangnya ke dalam mulut.

"Wah iya mbak dia kalau main gitu dimasukin mulut mainannya" (R11)

“Iya mbak apa yang nggak dia masukin ke mulutnya itu” (R14)

\section{2) Mencuci Tangan}

Dari analisis data hasil wawancara mendalam yang telah dilakukan didapatkan $(53 \%)$ atau 8 orang ibu mengajari dan membiasakan anak untuk cuci tangan dengan air mengalir dan sabun sebelum makan, setelah bermain, setelah BAB, dan sebelum tidur. Sedangkan $(47 \%)$ atau 7 orang ibu lainnya belum mengajarkan anaknya mencuci tangan dan atau hanya mencuci tangan dengan air mengalir saja.

"Iya mbak saya ajari gitu cuci tangan pakek sabun" (R01)

"Iya mbak tak biasakan dia itu"

"Iya mbak pakek sabun cair itu” (R04)

Perilaku Hidup Bersih dan Sehat (PHBS) menurut Kemenkes (2019) memiliki tujuan untuk meningkatkan kesejahteraan dan mencegah penyakit. Penyakit khususnya penyakit infeksi merupakan salah satu faktor penting yang 
mempengaruhi status gizi balita secara langsung. Balita yang menderita penyakit infeksi akan mengalami penurunan nafsu makan sehingga jumlah dan jenis zat gizi yang masuk ke dalam tubuh berkurang. Sebaliknya pada keadaan infeksi, tubuh membutuhkan zat gizi yang lebih banyak untuk memenuhi peningkatan metabolisme pada balita yang menderita infeksi terutama apabila disertai panas. Demikian pula sebaliknya, balita yang menderita gizi kurang akan mempunyai risiko terkena penyakit infeksi karena pada keadaan kurang gizi daya tahan tubuh balita menurun, sehingga kuman penyakit lebih mudah masuk dan berkembang (Kemenkes RI, 2014).

Salah satu cara untuk memperbaiki status gizi balita adalah dengan mencegah terjadinya infeksi penyakit. Pada usia 0 - 24 bulan balita suka memasukkan barang - barang dan makanan yang dipegang ke dalam mulutnya. Kebiasaan tersebut memberikan peluang besar bagi kuman penyakit untuk menginfeksi balita. Ibu selaku primary care memiliki peranan penting untuk melakukan pencegahan pada kebiasaan ini. Selain itu penting bagi ibu untuk mengajarkan dan membiasakan balita untuk melakukan cuci tangan. Apabila balita sejak dini sudah dibiasakan mencuci tangan diharapkan kedepannya kemungkinan terinfeksinya kuman dapat terminimalisir, sehingga risiko balita terkena penyakit berkurang dan status gizi dapat diperbaiki.

\section{Tema 5 : Kepatuhan Ibu Terhadap Program Puskesmas}

Kepatuhan ibu dalam melaksanakan program gizi buruk dari puskesmas dibagi menjadi empat subtema :

\section{1) Posyandu}

Dari analisis data hasil wawancara mendalam yang telah dilakukan didapatkan (73\%) atau 11 orang ibu rutin membawa anaknya ke posyandu tiap bulannya sedangkan (27\%) atau 4 orang ibu jarang atau tidak rutin membawa balitanya ke posyandu.

"Kalau posyandu rutin mbak" (R07)

"Rutin sih mbak cuma ya kadang di sini kadang di desa" (R09)

\section{2) Kepatuhan Pemberian PMT-P}

Dari analisis data hasil wawancara mendalam yang telah dilakukan didapatkan (67\%) atau 10 orang ibu memberikan biskuit puskesmas sebagai makanan 
tambahan untuk memperbaiki gizi balita dan balita mengkonsumsi sampai habis. Sedangkan (23\%) atau 5 orang ibu lainnya mencoba memberikan namun balitanya menolak atau kurang suka terhadap biskuit tersebut dan akhirnya tidak terkonsumsi atau terkonsumsi namun hanya 1 sampai 2 keping saja.

"Iya nyemil biskuit dari puskesmas itu mbak" (R04)

"Oh iya kalau nyemil kayak biskuit yang dikasih posyandu itu tapi ya gitu perlu dilumatkan juga kalau langsung gitu dia nggak mau” (P06)

\section{3) Imunisasi}

Dari analisis data hasil wawancara mendalam yang telah dilakukan didapatkan (87\%) atau 13 orang balita diimunisasikan secara lengkap oleh sang ibu sedangkan $(13 \%)$ atau 2 orang balita lainnya tidak diimunisasikan secara lengkap atau bahkan lupa apakah sudah mengikuti serangkaian tahapan imunisasi.

"Iya lengkap kok mbak (Imunisasi)" (R01)

"Lengkap mbak kalau imunisasinya" (R04)

\section{4) Obat Cacing}

Dari analisis data hasil wawancara mendalam yang telah dilakukan didapatkan (54\%) atau 8 orang ibu rutin memberikan obat cacing kepada balitanya setiap 6 bulan sekali sesuai dengan obat yang diberikan oleh puskesmas. Sedangkan (47\%) lainnya tidak memberikan obat cacing kepada balitanya.

"Iya mbak saya kasih obah cacing, dapet dari posyandu itu" (R03)

"Oh iya mbak konsumsi kok kalau obat cacing, 6 bulan sekali dapet dari posyandu itu” (R06)

Kepatuhan adalah suatu ketaatan terhadap tujuan yang telah ditentukan dalam program kesehatan dan kepatuhan dapat diukur dan diobservasi (Iswatiyah, 2016). Tingkat kepatuhan ibu terhadap program pemerintah dalam menangani masalah gizi buruk mempengaruhi proses perbaikan status gizi balita. Menurut penelitian yang dilakukan oleh Sugiarti dkk (2014) dan Fithria (2015), bahwa semakin patuh balita berkunjung ke posyandu, maka status gizi balita akan baik juga. Hal ini dapat dilihat dari balita yang patuh berkunjung ke posyandu memiliki persentase status gizi baik yang lebih tinggi (62,5\%) dibanding yang tidak patuh (10\%). Melalui kegiatan posyandu pertumbuhan dan perkembangan balita akan terpantau dengan 
baik, sehingga apabila terdapat suatu masalah puskesmas dapat dengan segera memberikan penangan yang sesuai.

Melalui kegiatan posyandu balita mendapatkan biskuit PMT-P, imunisasi, dan obat cacing. Tingkat kepatuhan ibu dalam memberikan biskuit PMT-P, imunisasi, dan obat cacing menunjukkan hasil yang sudah baik. Tetapi saran untuk ibu sebaiknya jika belum memberikan obat cacing kepada balitanya untuk mulai mencoba memberikan secara rutin, agar tujuan dari pemberian obat cacing dapat tercapai dan status gizi balita dapat membaik.

\section{Tema 6 : Konsultasi dengan Tenaga Kesehatan}

Dari analisis data hasil wawancara mendalam yang telah dilakukan didapatkan dari 15 ibu hanya terdapat (26\%) atau 4 orang ibu saja yang melakukan konsultasi ke tenaga kesehatan sedangkan sisanya tidak.

"Iya mbak tak konsulkan juga ke dokter" (R14)

"Oh iya saya bawa kebidan waktu itu mbak, katanya suruh kasih mentega blue band itu lo mbak ke susunya" (R06)

Melakukan konsultasi ke tenaga kesehatan merupakan salah satu upaya yang dilakukan oleh ibu untuk mengatasi masalah gizi pada balitanya. Usaha ini dipengaruhi oleh kemampuan ibu dalam mengakses pelayanan kesehatan dasar (Kemenkes, 2012). Usaha yang dilakukan ibu merupakan suatu bentuk respon terhadap konsep sehat - sakit (perilaku kesehatan). Menurut Notoatmodjo (2010) perilaku kesehatan dibagi menjadi 2 kelompok besar, yaitu perilaku orang sehat (health behavior) dan perilaku orang yang sakit. Perilaku orang yang sakit terjadi pada orang yang sudah mengalami masalah dengan kesehatannya atau yang sering disebut perilaku pencarian pelayanan kesehatan (health seeking behavior). Perilaku ini mencakup tindakan - tindakan yang diambil seseorang untuk memperoleh kesembuhan atas penyakit yang dideritanya.

\section{SIMPULAN DAN SARAN}

Perawatan yang dilakukan oleh ibu terhadap balitanya yang mengalami gizi buruk, yaitu : melakukan perubahan pola pemberian makan dengan strategi praktik pemberian makan yang aktif dan responsif, Ibu tidak hanya diam melihat kondisi balitanya yang mengalami masalah gizi namun melakukan usaha - usaha lainnya 
dengan memberikan makanan tambahan (selingan) berupa snack sehat yang berbahan lokal serta mengurangi konsumsi makanan ringan yang berlebihan, menerapkan Perilaku Hidup Bersih dan Sehat (PHBS) kepada anak dengan cara mencegah kebiasaan balita dalam memasukkan barang yang dipegang ke dalam mulut dan membiasakan balita untuk mencuci tangan dengan baik dan benar, patuh terhadap program puskesmas dengan rutin membawa balitanya ke posyandu, imunisasi secara lengkap, memberikan biskuit PMT-P sampai dengan habis, dan memberikan obat cacing secara rutin meskipun balita tidak mengalami cacingan, dan melakukan konsultasi lebih lanjut ke tenaga kesehatan untuk mengetahui penyebab pasti masalah gizi pada balita dan solusinya.

Hal yang perlu diperbaiki oleh ibu pada proses perawatan balita gizi buruk adalah dengan memperhatikan keseimbangan antara kuantitas dan kualitas atau kandungan nutrisi makanan, mengubah persepsi bahwa faktor keturunan adalah penyebab masalah gizi pada balita dan tetap melakukan usaha lain sampai status gizi balita membaik, dan memberikan vitamin penambah nafsu makan.

Saran untuk penelitian selanjutnya sebaiknya responden tidak hanya satu subjek saja (ibu) namun perlu melibatkan keluarga dan tenaga kesehatan.

\section{DAFTAR PUSTAKA}

Abidin, Zainal. (2012). Pengatur Pola Menu Makanan Balita untuk Mencapai Status Gizi Seimbang Menggunakan Sistem Inferensi Fuzzy Metode Sugeno. Skripsi untuk Memperoleh Gelar Sarjana, Program Studi Teknik Informatika, Fakultas Sains dan Teknologi Universitas Islam Negeri Maulana Malik Ibrahim Malang.

Arredondo, EM, Elder, JP, Ayala, GX, Campbell, N, Baquero, B \& Duerksen, S. (2011). Is parenting style related to childerns' healthy eating and physical activity in Lationo families?. Health Education Research. 21(6), pp. 862-871.

Depkes RI. (2016). Profil Kesehatan Kota Surabaya Tahun 2016. Dinas Kesehatan Kota Surabaya.

Depkes RI. (2017). Profil Kesehatan Kota Surabaya Tahun 2017. Dinas Kesehatan Kota Surabaya.

Depkes. (2011). Panduan Penyelenggaraan Pemberian Makanan Tambahan Pemulihan Bagi Balita Gizi Kurang (Bantuan Operasional Kesehatan). Kementrian Kesehatan RI Direktorat Jenderal Bina Gizi dan Kesehatan Ibu.

Fithria dan Nurul.A. (2015). Hubungan Pemanfaatan Posyandu dengan Status Gizi Balita di Kecamatan Kota Jantho. Idea Nursing Journal. Vol. VI, No. I. ISSN 2087 - 2879.

Herlina, M. S. (2014). Hubungan Pemberian Suplemen Multivitamin dengan Status Gizi Balita Usia 1 - 5 Tahun di Posyandu Pala VII Notoprajan Yogyakarta. 
Skripsi Program Studi Bidan Pendidik Jenjang DIV STIKES Aisyiyah Yogyakarta.

Kemekes direktorat promosi kesehatan dan pemberdayaan masayarakat. 2019. PHBS. http://promkes.kemkes.go.id/phbs. Diakses pada tanggal 22 April 2019.

Kementrian Kesehatan RI. 2016. Situasi Gizi Kecukupan Asupan Energi Penduduk Indonesia. (InfoDATIN) Pusat Data dan Informasi Kementrian Kesehatan RI. ISSN 2442-7659. hlm. 5-8

Kemetrian Kesehatan RI. (2014). Pedoman Gizi Seimbang. hlm. 4-20.

Khasanah, N. A., \& Sulistyawati, W. (2018). Karakteristik Ibu dengan Kejadian Gizi Kurang pada Balita 6-24 Bulan di Kecamatan Selat, Kapuas Tahun 2016. Strada Jurnal Ilmiah Kesehatan. ISSN : 2252-3847. Vol. 7, No. 1, hlm. 1-8.

Kusumanintyas. E. D., et al. (2017). Pola Pemberian Makanan Terhadap Status Gizi Usia 12 - 24 Bulan pada Ibu Bekerja. Public Health Perspective Journal. Unnes. p-ISSN 2528 - 5998, e-ISSN 2540 - 7945. hlm. 155 - 167.

Marmi \& Rahardjo. K. (2012). Asuhan Neonatus, Bayi, Balita, dan Anak Prasekolah. Yogyakarta: Pustaka Pelajar, hlm. 373 - 394.

Miko, A. dan Agus. H. A. (2017). Hubungan Berat dan Tinggi Badan Orangtua dengan Status Gizi Balita di Kabupaten Aceh. Journal Of Indonesian Nutrition Association. GIZI Indonesia, 40 (1) : 21 - 34. p-ISSN 0436-02565 e-ISSN2528 - 3874.

Mohseni, M., et al. (2017). Factors associated with malnutrition among under five-year-old children in Iran: A systematic review. Annals of Tropical Medicine and Public Health. Volume 10, Issue 5, pp. 1147 - 1158.

Nangalu, R., Pooni, P., Bhargav, S., \& Bains, H. (2016). Impact of malnutrition on pediatric risk of mortality score and outcome in Pediatric Intensive Care Unit. Indian Journal of Critical Care Medicine, 20(7), 385.

Natalia, L.D. (2013). Hubungan Kebutuhan Pangan Tingkat Keluarga dan Tingkat Kecukupan Zat Gizi dengan Status Gizi Balita di Desa Gondangwinangon tahun 2012 (Doctoral disertation, Diponegoro University)

Notoatmodjo, S. (2010). Promosi Kesehatan dan Perilaku. Jakarta : Rineka Cipta. hlm. 18-26.

Rezaei, O. M., Moodi, M., \& Moazam, N. (2014). Analyzing the level of knowledge and attitude of the mothers referring the urban health centers of Birjand about nutritional behaviors. Journal of Education and Health Promotion, 3(April), 37.

Septikasari, M. (2018). Status Gizi Anak dan Faktor Yang Mempengaruhi. Yogyakarta : UNY Press.

Sugiyarti, Retno, et. Al. (2014). Kepatuhan Kunjungan Posyandu dan Status Gizi Balita di Posyandu Karangbendo Banguntapan, Bantul, Yogyakarta. Journal Ners an Midwifery Indonesia (JNKI). Vol. 2, No. 3. Hlm : 141 - 146. ISSN 2354 - 7642.

Supriasa I. D. N., Bakri B, \& Fajar I., (2016). Penilaian Status Gizi Edisi 2. Jakarta : EGC hlm 21-25.

Suyatman, Billi., et al. (2017). Faktor Risiko Kejadian Gizi Kurang Pada Balita (Studi Kasus Di Wilayah Kerja Puskesmas Bandarharjo Kota Semarang). Jurnal Kesehatan Masyarakat. ISSN: 2356-3346. Vol. 5, No. 4, pp. 778-787 
Widayani, D. Maratina.,et al. (2016). Gambaran Pola Asuh Dan Pertumbuhan Balita Penderita Gizi Buruk Pasca Dirawat Di Rumah Gizi Semarang. Jurnal Kesehatan Masyarakat. ISSN: 2356-3346. Vol. 4, No. 3, hlm. 208-217.

Wiyono, Sugeng. (2016). Epidemiologi Konsep dan Aplikasi. Jakarta : Sagung Seto, hlm 121-122. 